\title{
Prehospital and First Hospital System Response to a Terrorist Attack in Bogotá, Colombia
}

\author{
Maria F Jimenez ${ }^{1}$, Andrés Becerra ${ }^{2}$, Sergio Cervera ${ }^{3}$, Elio F Sánchez ${ }^{4}$, Jorge Ospina ${ }^{5}$, Francisco J Henao ${ }^{6}$, Alexander Paz $^{7}$, \\ Gabriel Paredes ${ }^{8}$, María I Gutiérrez ${ }^{9}$, Juan C Puyana ${ }^{10}$
}

\begin{abstract}
Background: Assembling an effective medical response for an overwhelming number of casualties has become a priority worldwide. Terrorist attacks have been part of the Colombian contemporaneous history. On February 7, 2003, a terrorist car bomb explosion occurred inside a private club in Bogotá, causing the largest number of casualties of all terrorist attacks for over 15 years. The present study analyses the hospital and prehospital responses to this mass casualty event by characterizing the patterns of injury, resource allocation, and outcome in a tertiary-level hospital where most of the casualties were treated.

Materials and methods: This is a retrospective chart review of the patients brought to a single hospital (La Clínica del Country), which was the nearest to the terrorist attack. Demographics, severity of injury, patterns of injury, prehospital care, and outcomes were determined from the hospital medical records and government registries.

Results: Of the 240 victims, 35 died at the explosion site (immediate mortality 17\%). The 205 survivors were dispersed throughout the city, of whom 63 patients came to La Clínica del Country hospital. Most of these patients were evaluated only clinically and deemed not serious. The main mechanism of trauma was blunt (81.4\%). The mean injury severity score (ISS) was $5.6 \pm 8.3$. Ten patients required emergent surgical intervention and 14 patients were admitted. The in-hospital mortality was $20 \%$.

Conclusion: This mass casualty event was a true test for the Colombian emergency medical system and disaster preparedness. The medical response and resource optimization resulted in an overall mortality rate similar to those observed in the recent European and North American bombings. Despite the limited resources, the continuous challenge of terrorist's attacks in Colombia made the country feel the need for training and preparing the healthcare professionals, allowing effective delivery of medical care.
\end{abstract}

Keywords: Bombing, Mass casualty, Medical response, Terrorist attack.

\section{Resúmen}

Introducción: La organización de una respuesta médica efectiva a un número excesivo de víctimas de ataques terroristas se ha convertido en una prioridad en el mundo. Los ataques terroristas han sido parte de la historia colombiana contemporánea. El 7 de Febrero de 2003 , un carro bomba explotó en el interior de un club privado en Bogotá, resultando en el ataque terrorista con mayor numero de víctimas durante los últimos 15 años. El objetivo de este estudio es determinar la respuesta del sistema pre y hospitalario a un ataque terrorista masivo, caracterizar los patrones de lesión, utilización de recursos y desenlaces en un hospital de primer nivel, donde la mayoría de las víctimas fueron atendidas. Métodos: Este es un estudio retrospectivo de la revisión de 43 historias clínicas de 63 pacientes que fueron llevados al hospital privado más cercano después de un ataque terroristas. La información demográfica, la severidad, el patrón de las lesiones y los desenlaces fueron determinados a partir de las historias clínicas y los registros gubernamentales.

Resultados: Treinta y cinco personas murieron en la escena y 205 personas fueron lesionadas (mortalidad inmediata de 17\%). 63 pacientes fueron transferidos a nuestros hospitales. La mayoría de los pacientes fueron valorados clínicamente y no tenían lesiones serias. El principal mecanismos de trauma fue cerrado. El promedio de ISS fue 5.6 \pm 8.3. Diez pacientes requirieron intervenciones quirúrgicas de urgencia y 14 fueron admitidos al hospital. La mortalidad crítica fue de $20 \%$.

Conclusione: Este incidente fue un verdadero examen a nuestro sistema médico de emergencias y plan de desastres hospitalario. Nuestro sistema médico optimizó los recursos resultando en una mortalidad crítica similar a la de las bombas ocurridas en Europa y Norte América. El desafío permanente de confrontar los ataques terroristas en Colombia ha proporcionado entrenamiento y preparación para asegurar un cuidado médico efectivo, aun con recursos limitados.

Palabras clave: Ataque terrorista, Bomba, Evento con lesionados masivos, Respuesta medica.

Panamerican Journal of Trauma, Critical Care \& Emergency Surgery (2019): 10.5005/jp-journals-10030-1254

\section{BACKGROUND}

A mass-casualty incident from bombing has historically been defined as causing 30 or more casualties, which is the number that challenges the surge capacity of most emergency medical systems. Arnold et al. ${ }^{1}$ recently described the epidemiological outcomes, resource utilization, and emergency response of 44 worldwide mass-casualty terrorist bombings from 1996 to 2002. Immediate mortality (number of immediate deaths per number of injured) is related to multiple

\footnotetext{
${ }^{1}$ Department of Surgery, Universidad del Rosario, Bogotá, Cundinamarca, Colombia

2-4,6Department of Surgery, Pontificia Universidad Javeriana, Bogotá, Cundinamarca, Colombia

${ }^{5}$ Clinica del Country, Bogotá, Cundinamarca, Colombia

${ }^{7,8}$ Centro Regulador de Urgencias y Emergencias, Bogotá, Colombia

${ }^{9}$ Universidad del Valle, Cali, Valle del Cauca, Colombia

${ }^{10}$ Department of Surgery, University of Pittsburgh Medical Center at Presbyterian Hospital, Pittsburgh, Pennsylvania, USA
} 
factors such as the magnitude of the bomb and the location of the explosion. Bombings occurring within a confined space and those associated with a structural collapse are related to the highest immediate mortality $(68 \%$ mortality for the bombing that caused the structural collapse of the US Marine Battalion Landing Team Headquarters in Beirut in 1983), which tends to reduce the demand for hospital capacity. On the other hand, open-air explosions have a lower immediate mortality (0-4\%) and, therefore, lead to much greater utilization of emergency departments (Eds; 26 to $100 \%)^{2}$

Assembling an effective medical response for multiple casualties has become a priority worldwide. As the modern era of terrorism moved to urban settings, it is essential that civilian hospitals ensure an effective medical response to mass-casualty terrorist events. Therefore, a wide range of health providers must be trained for mass-casualty triage and treatment under overwhelming circumstances to optimize survival according to a systemic and hospital-wide "damage control" philosophy.

In contrast to most countries around the world, terrorism and bombing attacks are a domestic problem in Colombia. Terrorist attacks have been part of the recent history of Colombia and have affected common civilians. According to Medina et al., ${ }^{3}$ a total of 552 terrorist bombings occurred in Bogotá, Colombia, between 1996 and 2006. Figure 1 shows the site of most of the 552 terrorist attacks that occurred during these 10 years.
Corresponding Author: Maria F Jimenez, Department of Surgery, Universidad del Rosario, Bogotá, Cundinamarca, Colombia, Phone: +57 320492 8466, e-mail: mafejimenez2000@gmail.com

How to cite this article: Jimenez MF, Becerra A, Cervera S, et al. Prehospital and First Hospital System Response to a Terrorist Attack in Bogotá, Colombia. Panam J Trauma Crit Care Emerg Surg 2019;8(3):143-147.

Source of support: Funded in part by the Fogarty International Center: NIH Grant No. 1 D43 TW007560-01

\section{Conflict of interest: None}

From the registries of the City Emergency System, Police Department, and newspaper information, we determined that $55(10 \%)$ of these bombings resulted in 1 to 205 casualties. Four of those were mass-casualty incidents. On example was the bombing of a private club in Bogotá, which occurred near La Clínica del Country, a nondesignated trauma center. This center has a long-standing emergency medical response plan that heavily relied on the initial clinical assessment rather than extensive investigations to best use its limited resources.

The aim of this study was to analyze the prehospital and hospital response to mass casualties from a terrorist bombing and to characterize the patterns of injury, allocation of resources, and outcomes in this first line hospital where most of the casualties were treated.

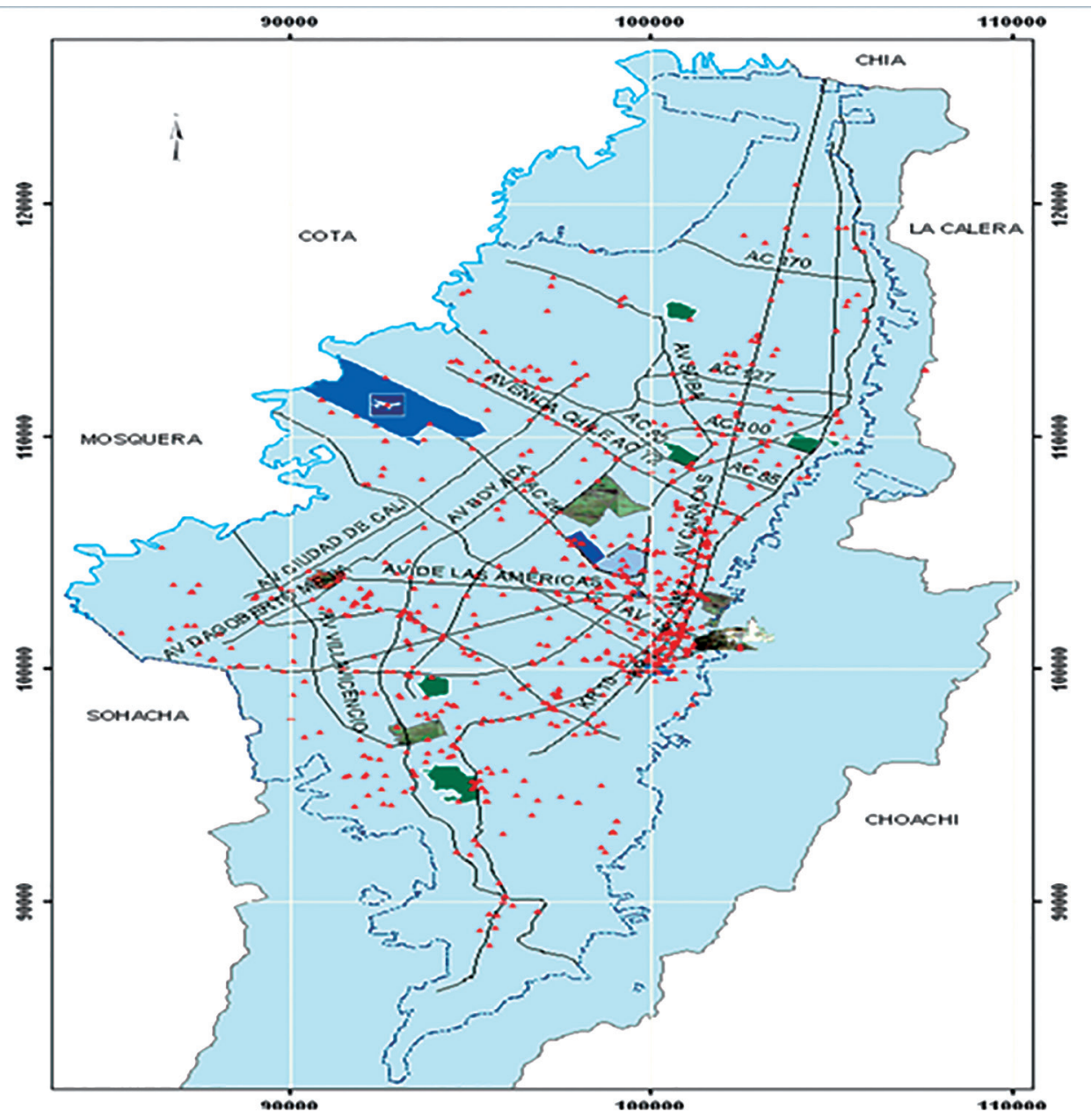

Fig. 1: Map of terrorist attacks in Bogotá from 1991 to 2005, red dots represent location of terrorist attacks in Bogotá city (Medina E, Nieto A, Senior A. SIG para la Creación de Planes de Contingencia contra Actos Terroristas. Universidad Distrital Francisco Javier de Caldas.) 


\section{Materials and Methods}

At 20:05 hours Friday night, February 7, 2003, a terrorist car bomb explosion occurred inside a private club in Bogotá (Club El Nogal), resulting in a confined-space explosion with partial structural collapse and fire. The explosion caused the largest number of casualties of all terrorist attacks in Colombia for the last 15 years. Bogotá's emergency system was alerted within minutes of the explosion, and the situation was managed according to the incident command system (HEICS). A modified simple triage and rapid treatment (START) system was used to triage the casualties to different hospitals. ${ }^{4}$

Demographics, severity of injury, patterns of injury, prehospital care, and outcomes were retrospectively collected from the La Clínica del Country medical records, Dirección de Policía Judicial (DIJIN) de la Policía Nacional de Colombia, and the City Emergency System of Bogotá (Centro Regulador de Urgencias de la Secretaría de Salud de Bogotá). Additional data were obtained from the emergency and radiology department hospital files, along with operating room reports and records of the in-hospital course including the intensive care unit (ICU). The study was approved by the Ethics Review Board of the La Clínica del Country in Bogotá, in 2006.

In-hospital analysis was performed solely on patients seen at the La Clínica del Country, where most of the casualties were transferred. La Clínica del Country, which is geographically near the club where the explosion occurred, is a private 200 -bed facility with 10 operating rooms, $10 \mathrm{ICU}$ beds, and 1 computed tomography (CT scanner). The ED has two trauma bays, wherein one bay consists of the portable X-ray device and another adheres to the advanced trauma life support guidelines of the Committee on Trauma, American College of Surgeons. At the time of the explosion, the hospital incident commander was the former Chairman of the Colombian Committee on Trauma of the American College of Surgeons.

Immediate trauma care was evaluated using two independent variables, namely, the level of experience of the decision maker and immediate access to the CT scanner and/or to the operating room. The severity of injuries was determined using the revised trauma score on admission to the ED and the injury severity score from medical records, surgical, or autopsy reports. Critical patients were defined by an injury severity score (ISS) >15 and critical mortality as the number of deaths in the critically injured survivors.

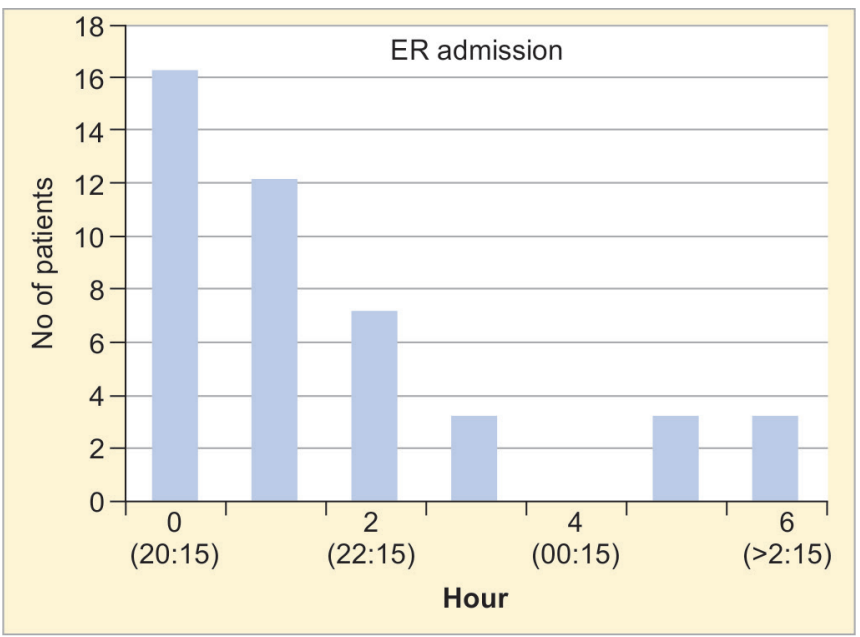

Fig. 2: Inflow casualties to the hospital
Data were gathered and analyzed using a Stata 6.0, version for Windows. Qualitative data were compared using the Pearson $\chi^{2}$ test or Fischer exact test for small samples. Quantitative data are expressed as means with standard deviation (SD). Differences between means were evaluated using analysis of variance or paired $t$ tests. A $p$ value 0.05 or less determined statistical significance.

\section{Results}

A total of 35 victims were declared dead at the scene and an additional 205 victims were injured by the confined-space explosion (immediate mortality 17\%). The city emergency medical system was alerted at 20:07 hours. Casualties were triaged using the modified START ${ }^{1}$ system, and 173 patients were transferred to 14 different hospitals. La Clínica del Country, the nearest hospital to the club, received 63 patients (37\% of all injured patients over 21 hours). As previously described in the literature, patients arrived following a biphasic distribution. The first patient to the ED arrived via ambulance 20 minutes after the explosion. Casualties were transferred mainly by ambulance (67\%) with intravenous fluid access (30\%) and immobilization of the spine (15\%). No intubations were performed at the scene or during transport. Using the hospital medical records, we were able to review only 19 patients who arrived within 1 hour of the explosion. The second influx of patients consisted of the extricated victims who arrived 4 hours after the explosion (Fig. 2). No correlation was observed between the arrival time and the ISS.

For most patients, the "decision maker" was either a surgeon or an internist. No delay was involved in caring/treating patients accessing the trauma/shock resuscitation room, undergoing $\mathrm{CT}$ scans or being transferred to the operating room. Most patients were solely assessed clinically, deemed not seriously injured, and discharged. In total, $38 \%$ of the casualties had no radiological study performed, and only $16 \%$ underwent a CT scan.

Most patients (81.4\%) suffered a blunt trauma (blast injury including blast wave, thrown against objects, or hit by debris), followed by burns (14\%), penetrating (2.2\%), and crushing injuries (2.3\%). Mean ISS was 5.6 \pm 8.3 . Figure 3 shows the distribution of the ISS intervals. The ISS of the only patient who died in the emergency room was 34 . In all, 14 emergency surgical procedures were performed on 11 patients, including debridement of wounds (15\%), fixation of fractures (13\%), and craniotomy (5\%). Seven patients were

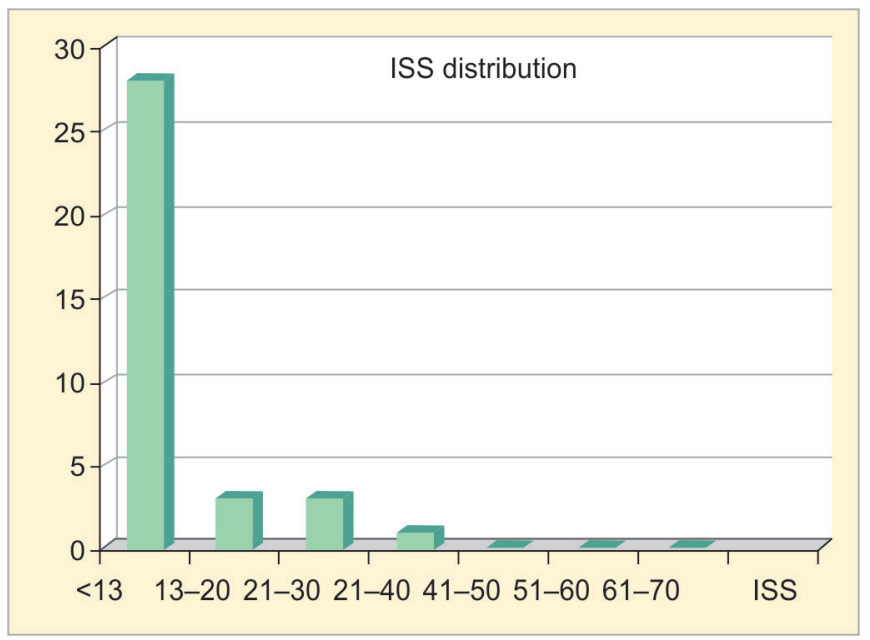

Fig. 3: Distribution of injury severity score 
Table 1: Summary of the outcomes

\begin{tabular}{|l|l|}
\hline Summary of the outcomes & Percent \\
\hline Blunt/penetrating & $47.7 / 2.2$ \\
\hline Radiologic studies & 61 \\
\hline Hospital admissions & 29.5 \\
\hline Surgical procedures & 25.0 \\
\hline Critical patients (ISS >16) & 11.4 \\
\hline Hospital LOS (days) & $6.2 \pm 3.0$ \\
\hline Immediate mortality & 17.0 \\
\hline Critical mortality & 20.0 \\
\hline Late Mortality & 3.5 \\
\hline
\end{tabular}

operated between 1 hour and 16 hours of the explosion. Surgical procedures were performed mostly by orthopedic surgeons, plastic surgeons, and neurosurgeons.

Fourteen patients (22\%) were admitted to the hospital, of whom four were admitted to the ICU. The mean hospital length of stay (LOS) was $6.5 \pm 3.0$ days, and the mean ICU LOS was $5.5 \pm 4.4$ days. Only five (11.4\%) patients were considered critically injured. Excluding the early ED death, only one critical patient died after admission (of traumatic brain injury). Thus, the in-hospital critical mortality was $20 \%$ (1 out of 4). The total mortality of all victims of the bombing was reported to be $3.5 \%$. Table 1 shows the summary of the outcomes.

\section{Discussion}

This manuscript analyses the medical response to the largest terrorist attack in Colombia in the past 20 years. Our analysis suggests that using clinical judgment over technology effectively reduced the use of resources in every component of the trauma system. Plain X-rays were performed only when the results would have an immediate impact on management, and CT scans were mainly reserved for patients with traumatic brain injuries. This response to mass casualties optimized the resources, resulting in a critical mortality rate $(20 \%)$, which is similar to that observed in other civilian bombings in Europe and North America. ${ }^{1,2,5-7}$

Immediate mortality in open-air explosions ranged from $7 \%$ to $9 \%$, increasing to $68 \%$ in confined-space explosions. We observed that the immediate mortality (17\%) was high, but like other confined-space explosions (Oklahoma 21\%, Argentine Mutual Insurance Agency in Buenos Aires 29\%), most survivors who were transferred to hospitals had no critical injuries.

Critical mortality is defined as the mortality among patients with ISS $>16$ and reflects the magnitude of the medical disaster, while critical and late mortality are considered indicators of the effectiveness of the trauma system. The critical (20\%) and overall late mortalities (3.5\%) in the Colombian event were similar to

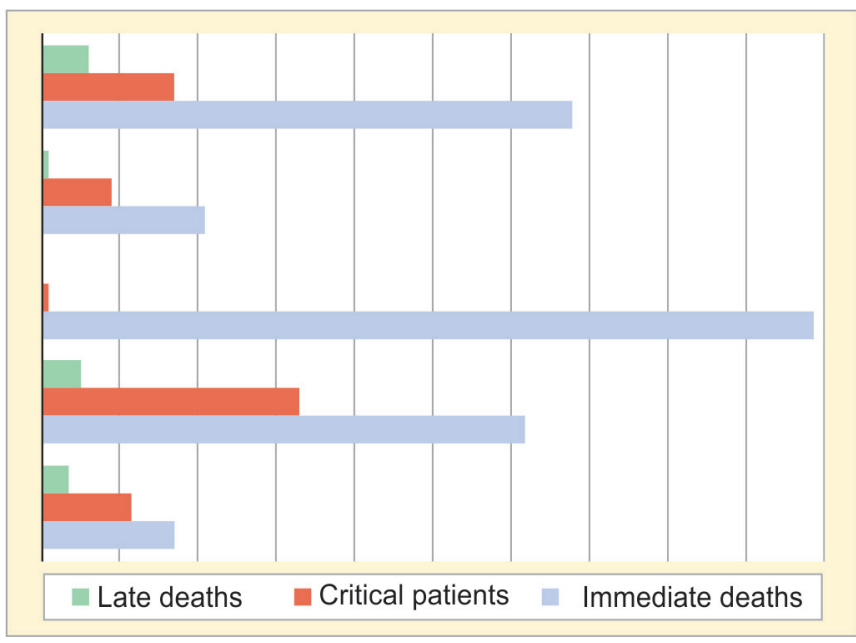

Fig. 4: Comparison between confined-space bombings

other bombing attacks (critical mortality of $15 \%$ in the London bombing and 29\% in Buenos Aires). As previously described, in confined-space explosions with structural collapse, most victims require wound and orthopedic care and use less resources than that required to treat victims of open-space bombings. Figure 4 shows the comparison between the Bogotá bombing attack and other terrorist events around the world.

\section{Conclusion}

Terrorist bombings serve as models for analyzing the factors influencing survival, patterns of injury, resource utilization, and outcomes. They are also a real-life test for emergency medical systems and hospital disaster plans. The emergency medical response to this incident was characterized by a hospital-wide "damage control" philosophy of optimizing limited resources based on initial clinical assessment. The long history of terrorist attacks in Colombia has provided training and preparation that resulted in effective prehospital and hospital medical care despite the resource limitation. Medical providers in Colombia must be actively trained and prepared for multiple-casualty incidents and utilize the hospital wide "damage control" philosophy.

\section{Acknowledgments}

This work was performed in Bogotá, Colombia, and was presented at the Resident's Research Competition of the American College of Surgeons representing region XIV in Washington D.C. in March 2008. This study was funded in part by the Fogarty International Center: NIH Grant No. 1 D43 TW007560-01.

\section{References}

1. Arnold JL, Tsai MC, Halpren P, et al. Mass-casualty, terrorist bombings: epidemiological outcomes, resource utilization, and time course of emergency needs (part I). Prehosp Disaster Med 2003;18(3):220-234. DOI: 10.1017/s1049023x00001096.

2. Leibovici D, Gofrit ON, Stein M, et al. Blast injuries: bus versus open air bombings-a comparative study of injuries in survivors of open-air versus confined-space explosiosn. J Trauma 1996;41(6):1030-1035. DOI: 10.1097/00005373-199612000-00015. 
3. Medina E, Nieto A, Senior A. SIG para la Creación de Planes de Contingencia contra Actos Terroristas. Universidad Distrital Francisco Javier de Caldas. Proyecto Curricular de Ingeniería Catastral y Geodesia; 2006.

4. Super G, Growth S, Hook R. START: simple triage and rapid treatment plan. Newport Beach (CA): Hoag Memorial Hospital Presbyterian 1994. Funded in part by The Fogarty International Center: NIH Grant No. 1 D43 TW007560-01.

5. Aylwin CA, Konig TC, Brennan NW, et al. Reduction in critical mortality in urban mass casualty incidents: analysis of triage, surge, and resource use after the London bombings on July 7, 2005. Lancet 2006;368(9554):2219-2225. DOI: 10.1016/S01406736(06)69896-6.

6. Biancolini CA, DelBosco CG, Jorge MA. Argentine Jewish community institution bomb explosion. J Trauma 1999;47(4):728-732. DOI: 10.1097/00005373-199910000-00019.

7. Hirschberg A, Scott BG, Granchi T, et al. How does casualty load affect trauma care in urban bombing incidents? A quantitative analysis. $J$ Trauma 2005;58(4):686-693; discussion 694-695. DOI: 10.1097/01. ta.0000159243.70507.86. 